\title{
ラット肝蔵におけるリノール酸メチル 自動酸化産物の吸収と代謝
}

\author{
大荒田素子*, 宮 沢陽 夫* \\ 藤 本 健四郎*，金 田 尚 志** \\ *東北大学農学部食糧化学科 \\ **郡山女子大学家政学部食物栄盖学科
}

\author{
Absorption and Metabolism of Autoxidation Products \\ of Methyl Linoleate in Rat Liver \\ Motoko OARADA,* Teruo MIYAZAWA,* Kenshiro FUJIMOTO* \\ and Takashi KANEDA** \\ *Department of Food Chemistry, Tohoku University, Sendai 980 \\ **Department of Food and Nutrition, Kohriyama Women's College, Kohriyama 963
}

Nippon Eiyō Shokuryō Gakkaishi (J. Jpn. Soc. Nutr. Food Sci.) 40, 117 121 (1987)

To study the toxicity of low molecular weight (LMW) compounds formed during the autoxidation of oils, ${ }^{14} \mathrm{C}$-labeled primary monomeric compounds (methyl linoleate hydroperoxides) and secondary oxidation products, i.e., polymer and LMW compounds prepared from autoxidized methyl[U-14C]linoleate hydroperoxides (MLHPO), were orally administered to rats (each $50 \mathrm{mg} / 200 \mathrm{~g}$ body wt.), and their radioactive distributions in the liver and in the hepatic lipids were compared.

When ${ }^{14} \mathrm{C}$-labeled MLHPO, polymer and LMW compounds were intubated, the radioactivities found in the liver were $2.3 \%, 2.2 \%$ and $6.9 \%$ of total activity administered, respectively. Among the radioactivities found in liver, the ${ }^{14} \mathrm{C}$ detected in Folch's chloroform layer was $40.1 \%$ for MLHPO, 33.7 $\%$ for polymer, and $9.4 \%$ for LMW compounds. Therefore, LMW compounds from MLHPO autoxidation seem to be moreeasily absorbed in rat liver than polymer and MLHPO, and most of them are suggested to exist as hydrophilic conjugates in the liver.

In the hepatic lipid fractions, the greater part of the radioactivities were distributed in triglycerides and phospholipids after administration of ${ }^{14} \mathrm{C}$-labeled MLHPO, polymer and LMW compounds. In the constituent fatty acids of liver total lipids, ${ }^{14} \mathrm{C}$ was mainly incorporated into normal saturated and monoenoic acids with carbon chains of 16 and 18.

The re-utilization of autoxidation products as the component fatty acids in the liver may reflect the detoxicative metabolism in rats. The high toxicity of LMW compounds may relate to their easiness for absorption into the liver and preferential formation of hydrophilic conjugates owing to their chemical structures with polar functionals such as aldehydic groups.

(Received August 25, 1986)

油脂の酸化劣化で生じる過酸化脂質類の毒性や栄養上 の問題点については, 現在までにかなり詳細に調べられ

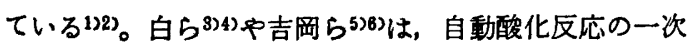
生成物である脂質七ドロペルオキシドより，ヒドロベル オキシドの分解で生じた低分子成分のほらが毒性が強い ことをすでに明らかにしている。前報》で著者らは、リ ノール酸メチルヒドロペルオキシド（MLHPO）をさら

\footnotetext{
* T980 仙台市堤通雨宮町 1-1

** T963 郡山市開成 3-25
}

に自動酸化して生じた低分子成分がヒドロベルオキシド 単量体や高分子重合物（おもにリノール酸メチルヒドロ ペルオキシド二量体) より体内に吸収されやすく種々の 臓器に速やかに移行すること,さらに低分子分解産物は 代謝回転が速く尿中への排泄速度も早いことをラットを 用いた実験で明らかにした。

本研究では, ラットの体内に吸収された脂質酸化生成

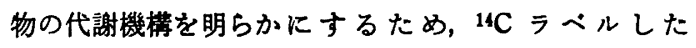
MLHPO とその分解生成物および重合物をそれぞれラッ 
トに経口投与したときの肝蔵中の脂溶性画分への ${ }^{14} \mathrm{C} の$ 分布状態を調べた。なお，本実験ではラットが下浰をし ない程度の比較的少量の脂質酸化物を投与した。

\section{実 験 方 法}

\section{1. ${ }^{14} \mathrm{C}$ 標識酸化物の調製}

前報7) と同様の方法で, [U-14C]リノール酸のメチル エステル (New England Nuclear) から, ${ }^{14} \mathrm{C}$ ラベル した高分子重合物 (polymer), リノール酸メチルヒドロ ペルオキシト (MLHPO) および低分子分解物 (LMW) の各画分を得た。すなわち，サフラワー油から尿素付加

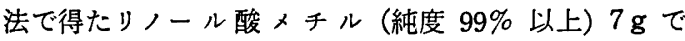
[U-14C] リノール酸メチル $(50 \mu \mathrm{Ci})$ を希釈したのち，乾 蜗空気を通して自動酸化し，ドライカラムクロマトグラ フィーによりほぼ純粋な MLHPO（過酸化物洒 6,075

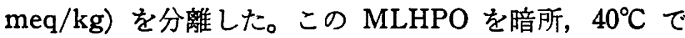
60時間さらに自動酸化したものをベンゼンを溶出剤とし た充填剂 Bio-Beads S-X 3 (BioRad Laboratories) に よるゲルカラムクロマトグラフィーに供し，3画分を分 離した。得られた三つの画分は，日立 115 型分子量測定 装置による平均分子量の測定およびヶイ酸薄層クロマト クラムより，それぞれ主として MLHPO の二量体から 成る polymer 画分, MLHPO 画分および LMW 画分 であることを確認した。なおここで得られた LMW 画 分は, ヒドロキシあるいはヒドロペルオキシアルケナ 一ルを主成分とし，他に多数の低分子化合物から成る (4-ヒドロキシ-2-ノネナール40\%，8-ヒドロキシィチル オクタノエート16.1\%，10-フォルミルメチル-9-デセ， エート $4.1 \%$ ，その他 $39.8 \%$ ことをガスクロマトグラ フィーマススペクトロメトリーで確認した7)。

\section{2. ラットへの脂㲘過酸化物の投与}

前報》に従い，市販固型飼料（船橋農場 F-2）で予備 飼有した体重約 $200 \mathrm{~g}$ の Wistar 系雄ラットを 12 時間 絶食させたのち， ${ }^{14} \mathrm{C}$ ラベルした MLHPO，LMW およ び polymer の 3 画分をそれぞれ 5 匹のラットに胃ゾン デを用いて $50 \mathrm{mg} / 200 \mathrm{~g}$ 体重ずつ経口投与した。前報7 の実験から，LMW 画分は投与 6 時間後に肝蔵をはじめ とする各蔵器への ${ }^{14} \mathrm{C}$ の取込みが最大になることがわか ったので，本実験においても酸化物の投与 6 時間後にェ ーテル麻醉下心臓採血をした後, 肝臓を摘出し，分析に 供した。

\section{3. 肝脂質の抽出と脂澌クラスへの放射能分布の分析}

酸化生成物を経口投与したラットから得た肝臓の一部 を前報》をと同様に $1 \mathrm{~N} \mathrm{NaOH}$ で溶解し， $0.98 \mathrm{~N} \mathrm{HCl}$ で 中和したのち, トルェンシンチレーションカクテルを加 え，肝臓に取り込まれた全放射能を測定した。また，肝 臓の総脂質を Folch 法8)で抽出した。得られた総脂質
を, へキサン: ジェチルエーテル : 酶酸 $(80: 20: 1$ ま たは $50: 50: 1, \mathrm{v} / \mathrm{v} / \mathrm{v})$ を展開溶媒とするケイ酸 (Kiesel gel 60, Merck) 薄層クロマトグラフィー (TLC) に供し，各脂質クラスを分離した。TLC 上の各脂質ク ラスの検出にはヨウ素蒸気を用いた。TLC 上の各脂質 クラスのパンドをかき取り,クロロホルム：メタノール $(2: 1, \mathrm{v} / \mathrm{v})$ でケイ酸から脂質を抽出し, トルエンシン チレーションカクテルを加えて Aloka 液体シンチレー ションシステム LSC-903 により放射能を測定した。

\section{4. 脂肪酸への放射能分布の分析}

酸化物を投与したラットの肝総脂質に，5\%ーメタノー ル性塩酸を加え，4時間還流加熱したのちへキサン抽出 して脂肪酸メチルエステルを得た。この脂肪酸メチルエ ステルをへキサン：ジェチルェーテル：酶酸（70:30： 1，v/v/v）を展開溶媒とする Kiesel gel 60 TLC に供 し, 脂肪酸メチルエステルを極性に応じて，ノルマル脂 肪酸、ヒドロキシ酸およびその他の成分に分離した。ヨ ウ素蒸気で TLC 上の各スポットを検出し，ケイ酸をか き取り，へキサンで脂肪酸メチルエステルを抽出しこ れにトルェンシンチレーションカクテルを加え, 放射能 を測定した。

また，肝総脂質の脂肪酸メチルエステルを，一キ廿 ン: エーテル：䣫酸（80:20:1, v/v/v）を展開溶媒と する硝酸銀含浸 Kiesel gel 60 TLC (12.5\% 硝酸銀溶液 を十分に噴蓩したのち， $110^{\circ} \mathrm{C} て ゙ 1$ 時間活性化したも の9)）に供し，不飽和度に応じて脂肪酸メチルエステル を分離した10)。TLC 上の脂肪酸メチルエステルのスポ

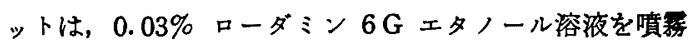
後, UV 照射下で検出した。TLC 上の脂肪酸メチルエ ステルの各バンドをかき取り，へキサンで抽出し，これ にトルエンシンチレーションカクテルを加え放射能を測 定した。

一方，肝総脂質から得た脂肪酸メチルエステルを，酸 化白金を触媒に用いて水素添加し，飽和化した。この飽 和化脂肪酸メチルエステルはアセトニトリル：テトラヒ ドロフラン（85:15，v/v）を展開溶媒とした KC 18 (Whatman) 逆相 TLCに供し, 飽和化脂肪酸メチルエ ステルを炭素数の差により分離した。TLC 上の各スボ ットの検出は, 孷素数 8〜14 のものは $0.03 \%$ ローダミ

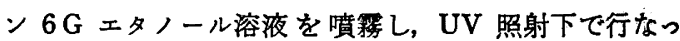
た。炭素数 16，18 および 20 のスポットは，1\% $\beta$-シ クロデキストリン (30\%エタノール溶液) を噴霧して検 出した。炭素数に応じて分離された飽和化脂肪酸メチル エステルの各スポットをかき取り，へキサン抽出部にト ルエンシンチレーションカクテルを加え放射能を測定し た。 
Table 1. Radioactivity in liver of rats $6 \mathrm{hr}$ after intubation of ${ }^{14} \mathrm{C}$-labeled oxidation products of methyl linoleate.

\begin{tabular}{|c|c|c|c|}
\hline \multicolumn{2}{|l|}{ Distribution } & & $\begin{array}{r}\text { MLHF } \\
(\mathrm{dpm} \times 10\end{array}$ \\
\hline \multicolumn{2}{|l|}{ Total liver } & 30 & \\
\hline \multicolumn{2}{|c|}{ Folch's chloroform layer } & 12 & 3 \\
\hline \multicolumn{3}{|c|}{$\begin{array}{l}\text { Total activity of labeled compounds } \\
\text { administered }\left(\mathrm{dpm} \times 10^{-2}\right)\end{array}$} & 13,634 \\
\hline \multicolumn{4}{|c|}{$\begin{array}{l}\text { MLHPO, }{ }^{14} \mathrm{C} \text {-labeled methyl linoleate hydropero } \\
{ }^{44} \mathrm{C} \text {-labeled low molecular weight compounds. } \\
\text { * Percentage of }{ }^{14} \mathrm{C} \text { to total liver. }\end{array}$} \\
\hline \multicolumn{4}{|c|}{$\begin{array}{l}\text { Table 2. Distribution of radioactivity in liver } \\
\text { lipids of rat } 6 \mathrm{hr} \text { after intubation of } \\
{ }^{14} \mathrm{C} \text {-labeled compounds. }\end{array}$} \\
\hline \multirow[b]{2}{*}{ Distribution } & \multicolumn{3}{|c|}{ Fractions administered } \\
\hline & $\underset{(\%)}{\operatorname{MLHPO}}$ & $\begin{array}{c}\text { Polymer } \\
(\%)\end{array}$ & $\underset{(\%)}{\operatorname{LMW}}$ \\
\hline Cholesterol esters & 3.0 & 2.7 & 3.9 \\
\hline Triglycerides & 33.3 & 36.9 & 44.7 \\
\hline Free fatty acids & 11.4 & 13.1 & 5.0 \\
\hline $\begin{array}{c}\text { Cholesterol+ } \\
\text { diglycerides }\end{array}$ & 9.0 & 7.7 & 13.3 \\
\hline Monoglycerides & 9.0 & 4.1 & 5.0 \\
\hline Phospholipids & 34.3 & 35.5 & 28.1 \\
\hline
\end{tabular}

\section{実 験 結 果}

\section{1. 肝矔への ${ }^{14} \mathrm{C}$ の分布}

Table 1 に, 肝贜に取り込まれた全 ${ }^{14} \mathrm{C}$ 量に対する脂 溶性成分中の ${ }^{14} \mathrm{C}$ の割合を示した。MLHPO p polymer を投与したときに比べ LMW を投与した場合，肝臓の 脂溶性画分への放射能の取込みは $9.4 \%$ と低かった。一 方, MLHPO 投与では肝 ${ }^{14} \mathrm{C}$ 量の $40.1 \%$ か, polymer 投与では $33.7 \%$ が脂溶性画分中に認められた。なお， 投与した ${ }^{14} \mathrm{C}$ 酸化物の肝臓佀取り込まれた割合は， ${ }^{14} \mathrm{C}$ MLHPO 投与では $2.3 \%$, polymer では $2.2 \%, \mathrm{LMW}$ では6.9\%であった。すなわち，MLHPO p polymer に比へ， LMW 由来の ${ }^{14} \mathrm{C}$ は, 肝臓中に多く分布してい たが，肝脂質画分への分布率は低いといえた。

\section{2. 肝脂兵中の ${ }^{14} \mathrm{C}$ の分布}

TLC で分離された肝䁍の各脂質クラスへの ${ }^{14} \mathrm{C}$ 分布 を Table 2 と示した。いずれの酸化生成物を投与した場 合でも，トリグリセリドとリン脂質に最も多く ${ }^{14} \mathrm{C} か ゙$ 分 布していた。姫に，TLC 上でコレステロールエステ ル，遊崔脂肪酸，コレステロール+ジグリセリト，モノ
Table 3. Radioactivity in fatty acid methylesters derived from liver total lipids of rats $6 \mathrm{hr}$ after intubation of ${ }^{14} \mathrm{C}$-labeled compounds.

\begin{tabular}{lrcr}
\hline \hline & \multicolumn{3}{c}{ Fractions administered } \\
\cline { 2 - 4 } Distribution & $\begin{array}{c}\text { MLHPO } \\
(\%)\end{array}$ & $\begin{array}{c}\text { Polymer } \\
(\%)\end{array}$ & $\begin{array}{c}\text { LMW } \\
(\%)\end{array}$ \\
\hline $\begin{array}{c}\text { Normal fatty acid } \\
\text { methylesters }\end{array}$ & 85 & 100 & 100 \\
$\begin{array}{c}\text { Unidentified } \\
\text { Hydroxy fatty acid } \\
\text { methylesters }\end{array}$ & 2 & 0 & 0 \\
$\begin{array}{c}\text { Unidentified } \\
\text { Unidentified }\end{array}$ & 5 & 0 & 0 \\
\hline \hline
\end{tabular}

グリセリドの各画分に相当するパンドにも量は少ないが ${ }^{14} \mathrm{C}$ が分布していた。

\section{3. 權成脂肪酸への ${ }^{14} \mathrm{C}$ の分布}

${ }^{14} \mathrm{C}$ ラペルした酸化物を経口投与したラットの6 時間 後の肝臓の総脂質から得た脂肪酸メチルエステル中の ${ }^{14} \mathrm{C}$ 量を Table 3 に示した。 polymer および LMW 画 分を投与した場合，極性官能基をむたない普通の直鎖脂 肪酸のみに ${ }^{14} \mathrm{C}$ が検出された。MLHPO 投与の場合に は，直鎖ノルマル脂肪酸には $85 \%$ の ${ }^{14} \mathrm{C}$ が分布し、ほ がヒドロキシ脂肪酸などの極性成分にも ${ }^{14} \mathrm{C}$ が検出さ れた。なお，いずれの酸化物を投与した場合でも，ヒド ロペルオキシル基に特有な $N, N$-dimethyl paraphenylenediamine 陽性のスポットはTLC 上に認められなか った。

肝総脂質から得た脂肪酸メチルエステルの不飽和度の 違いによる ${ }^{14} \mathrm{C}$ 分布を, Table 4 に示した。 MLHPO, polymer および LMW 投与の場合とも，飽和酸に最も 多く ${ }^{14 C}$ か取り込ま机ていた。 polymer 投与の場合, MLHPO P LMW 投与のときよりモノェン酸に比較的 
Table 4. Distribution of radioactivity in fatty acid methylesters derived from liver total lipid of rats $6 \mathrm{hr}$ after intubation of ${ }^{14} \mathrm{C}$-labeled compounds.

\begin{tabular}{cccc}
\hline \multirow{2}{*}{ Distribution } & \multicolumn{3}{c}{ Fractions administered } \\
\cline { 2 - 4 } & $\begin{array}{c}\text { MLHPO } \\
(\%)\end{array}$ & $\begin{array}{c}\text { Polymer } \\
(\%)\end{array}$ & $\begin{array}{c}\text { LMW } \\
(\%)\end{array}$ \\
\hline $0^{*}$ & 89.2 & 52.4 & 81.0 \\
1 & 10.8 & 47.6 & 19.0 \\
2 & 0.0 & 0.0 & 0.0 \\
3,4 & 0.0 & 0.0 & 0.0 \\
\hline \hline
\end{tabular}

* Number of double bond of fatty acids.

多くの ${ }^{14} \mathrm{C}$ が検出された。ジェントリエン, テトラェ ンなどのポリエン酸への ${ }^{14} \mathrm{C}$ 分布は, いずれの場合も認 められなかった。

肝総脂質から得た構成脂肪酸メチルェステルを水素添 加し，逆相 TLCで脂肪酸を炭素数の差により分離した 時の ${ }^{14} \mathrm{C}$ 分布を Table 5 に示した。各酸化物を投与した 場合とも, ラット肝総脂質の構成脂肪酸のらち炭素数 16 に最も多く，ついで炭素数 18 の脂肪酸に多く ${ }^{14} \mathrm{C}$ が取 り込まれていた。この場合，投与した各酸化物による差 は認められなかった。MLHPO 投与の場合, 岸素数 20 の脂肪酸への ${ }^{14} \mathrm{C}$ 分布も認められた。

\section{考察}

本実験では油脂劣化で生じる低分子の二次酸化生成物 の強い毒性の原因を探るため，U-14C ラベルリノール酸 から調製した MLHPO と，おもに MLHPO二量体か ら成る polymer および低分子化合物の 3 画分を, それ ぞれラットに経口投与したときの, 肝臓脂質への ${ }^{14} \mathrm{C}$ 分 布の比較を行なった。前報》ですでに明らかにしたよう に, この場合の低分子化合物 (LMW) のなかには 4-ヒ ドロキシ（ヒドロペルオキシ)-2ーノネナール，8ーヒドロ キシ（ヒドロベルオキシ）メチルオクタノエートおよび 10-フォルミルメチルー9-デセノェートがその主成分とし て含まれていた。

${ }^{14} \mathrm{C}$ ラペル酸化物をラットに経口投与すると, LMW 投与の場合，呼気 ${ }^{14} \mathrm{CO}_{2}$ 排泄量は投与後 $2 \sim 4$ 時間で MLHPO p polymer 投与の場合の約 5.5 倍, $4 \sim 6$ 時 間後で約 3.5 倍に達する7。 Table 1 亿示されたよらに, 投与 6 時間後の肝臓中の ${ }^{14} \mathrm{C}$ 量は, LMW の場合全投与 量の 6.9\% であり, MLHPO p polymer の取込まれ率 (それぞれ 2.3，2.2\%）より高く，この結果は前報》と 一致した。すなわち，LMW はラット体内に吸収移行さ れやすいことを示した。しかし，肝の脂溶性画分中へ の ${ }^{14} \mathrm{C}$ 分布は, MLHPO (全肝臟中 ${ }^{14} \mathrm{C}$ の 40.1\%) ゃ
Table 5. Distribution of radioactivity in fatty acids derived from liver total lipid of rats $6 \mathrm{hr}$ after intubation of ${ }^{14} \mathrm{C}$-labeled compounds.

\begin{tabular}{crrr}
\hline \multirow{3}{*}{ Distribution } & \multicolumn{3}{c}{ Fractions administered } \\
\cline { 2 - 4 } & $\begin{array}{c}\text { MLHPO } \\
(\%)\end{array}$ & $\begin{array}{c}\text { Polymer } \\
(\%)\end{array}$ & $\begin{array}{c}\text { LMW } \\
(\%)\end{array}$ \\
\hline $14^{*} \leqq$ & 0.0 & 0.0 & 0.0 \\
16 & 73.0 & 89.2 & 77.8 \\
18 & 19.7 & 10.8 & 22.2 \\
20 & 7.3 & 0.0 & 0.0 \\
$22 \geqq$ & 0.0 & 0.0 & 0.0 \\
\hline \hline
\end{tabular}

* Carbon number of fatty acids.

polymer (33.7\%) に比べ, LMW では 9.4\%であり, LMW が脂溶性画分中にあまり多くは取り込まれていな いことがわかった(Table 1).これは, LMWが MLHPO や polymer より肝脂質として再利用されにくいことを 示すと思われた。よって, 肝蔵では, 脂溶性区分より水 溶性区分に LMW 由来の ${ }^{14} \mathrm{C}$ か取り込まれやすいと考 えられ，LMW の分子量やヒドロキシル基やアルデヒド 基などの極性官能基の存在がこの結果に大きく影響して いると考えられた。

Esterbauer ら ${ }^{1112)}$ は, 種々の飽和および不飽和アル デヒド化合物が還元型クルタチオンやシステインの SH 基に反応してアダクトを形成することを明らかにしてい る。また, アルデヒドはアミノ酸とシッフ塩基様物質を 形成する。よって，アルデヒド基を含む化合物からおも に成っている LMW が肝臓中で，タンパク質やアミ， 酸のアミノ基とアダクトを形成して水溶性区分に多く存 在することが示唆された。ヒドロキシ（ヒドロペルオキ シ）フルケナールがチトクロムcなどを変性させたり， リパーゼやクルコース 6-ホスファターゼを失活させる ことが知られている ${ }^{13) 14}$ 。水溶性区分中K LMW-14C が多く分布しやすいことを考㕕合わせると，LMW の強 い性の原因の一つとして，このような䣼素失活作用に よる肝機能低下も考えられた。

肝臓の脂溶性成分に取り込まれた MLHPO, polymer, LMW 由来の ${ }^{14} \mathrm{C}$ は, ほとんどがヒドロキシル基や七 ドロペルオキシル基をもたない普通の脂肪酸として存在 し, その大部分は炭素数 16 や 18 の飽和脂肪酸で, おも にトリクリセリドやリン脂質の構成脂肪酸になっている ことがわかった (Table 2〜5)。これらの結果は, 肝䁧 の脂溶性画分に取り込まれる LMW の大部分は，一度 分解反応を受けたのち脂肪酸に再合成され，他の脂肪酸 と同様に肝脂質として再利用されていることを示嘫して

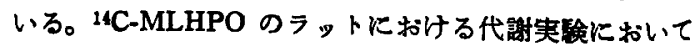


は，肝贜の脂溶性画分に取り込まれた MLHPO の一部 がタルタチオンペルオキシダーゼなどによる罢元や脱 水反応を受け，ジェン酸やトリェン酸になりトリクリセ リドやリン脂質の構成脂肪酸になるとい5 Bergan ら の説もある。しかし，今回の実験では，肝臟中の構成脂

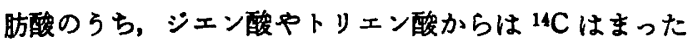
く娭出されず，この説とは明らかに異なった結果が得ら れた。中津川，金田 ${ }^{16)}$ は、ラットに MLHPO を経口投 与した場合，腸間リンバ液に投与量の $0.23 \%$ ではある が末変化の MLHPO が存在していることを高速液体ク ロマトクララフィを用いた実験で確認している。polymer や LMW 区分中のヒドロペルオキシド基などの官 能基をもつ化合物についてもごく微量ながら未変化で肝 臓中に取り込まれて，毒性発現の一因となる可能性も考 えられた。

今回の実験では，下利をしない程度の少量の酸化物を ラットに投与してその吸収と肝脂質への代謝を調べた。 酸化物をより大量に投与したり逨続的に与えた場合，あ るいは投与前の絶食処理の仕方によっては， ${ }^{14} \mathrm{C}$ の吸収 移行のされ方が本実験と異なる場合もあると思われた。 本実験で示された肝脂質への酸化物の取込みは，ラッ ト体内での酸化油脂の無毒化ないし再利用を反映したも のであろう。LMW の強い毒性発現のメカニズムを知る ためには，肝臟の水溶性成分中の存在形態について，ま た㱳中への排泄形態についても究明していく必要がある と思われた。

\section{要 約}

U-14C-ラベルしたリノール酸メチルヒドロペルオキシ ト (MLHPO), polymer 画分 (おむに MLHPO二量体 から成る）およびヒドロキシ（ヒドロペルオキシ）フル ケナールを多く含む低分子分解産物（LMW）をそれぞ れ $50 \mathrm{mg}$ ずつ体重 $200 \mathrm{~g}$ のラットに経口投与し，投与 6 時間後の肝臟中の脂溶性成分への ${ }^{14} \mathrm{C}$ の分布を調べ， これら脂質酸化産物の代謝系を比較した。

本実験では下浰をおこさない程度の比較的少量の酸化 物を投与した。 MLHPO投与の場合，全投与量の $2.3 \%$, polymer では $2.2 \%$, LMW では $6.9 \%$ の ${ }^{14} \mathrm{C}$ が肝蔵 飞取り込まれた。肝臟の全 ${ }^{14} \mathrm{C}$ のらち脂溶性区分に存在 した ${ }^{14} \mathrm{C}$ 量は，MLHPO 投与の場合 $40.1 \%$, polymer
の場合 33.7\%，LMW では 9.4\% であった。よって, LMW は MLHPO p polymer より肝臓に取り込まれ やすいか，脂溶性成分としては多くは存在しないことが わかった。 MLHPO, polymer および LMW 投与の場 合とも， ${ }^{14} \mathrm{C}$ は肝臓のトリグリセリドとリン脂質に多く 分布し, これら肝脂質の構成脂肪酸のうちとくにノルマ ルの炭素数が 16 と 18 で飽和酸ないしモノェン酸として 存在することがわかった。これら肝脂質への再利用は油 脂酸化物の無毒化を反映したと思われた。LMW の強い 毒性は，肝臟への吸収のされやすさ，LMW に含まれる アルデヒド基などの極性官能基の存在，および水溶性区 分への取り込まれやすさが，大きく関係していると思わ れた。

\section{文献}

1）金田尚志：過酸化脂質と栄養（五十峝修, 金田尚 志, 福場博保, 美濃 真編), 51 (1986), 光生館 (東京)

2）五十嵐脩, 宮沢陽夫 : 過酸化脂質と生体（内山 充, 松尾光芳, 情俄井勝編), 79 (1985), 学会出 版センター (東京)

3）白 台鴻，金田尚志：栄養之食糧，29，85(1976)

4) 白 台鴻, 金田尚志: 油化学, 27, 851 (1978)

5) 吉岡倭子, 金田尚志: 油化学, 21, 316 (1972)

6) 吉岡偻子, 金田尚志: 油化学, 23, 321 (1974)

7) Oarada, M., Miyazawa, T. and Kaneda, T. : Lipids, 21, 150 (1986)

8) Folch, J., Lees, M. and Sloanestanley, G.H.: J. Biol. Chem., 226, 497 (1957)

9) Privett, O.S., Blank, M.L., Cooding, D.W. and Nickell, E.C. : J. Am. Oil. Chem. Soc., 42, 381 (1965)

10) Malins, D.C. and Mangold, H.K. : J. Am. Oil. Chem. Soc., 37, 576 (1960)

11) Esterbauer, H., Ertl, A. and Scholz, N. : Tetrahedron, 32, 285 (1976)

12) Esterbauer, H., Zollner, H. and Scholz, N. : Z. Naturforsch., 30 c, 466 (1975)

13）吉岡倭子, 鈴木勝久, 金田尚志：油 化 学, 21 , 881 (1972)

14) Benedetti, A., Comporti, M. and Esterbauer, H. : Biochim. Biophys. Acta, 620, 281 (1980)

15) Bergan, J.G. and Draper, H.H. : Lipids, 5, 976 (1970)

16) 中津川研一, 金田尚志 : 油化学, 32, 361(1983)

（昭和 61 年 8 月 25 日受理） 